\title{
Pengaruh Mobilisasi Dini terhadap Penyembuhan Luka dan Peningkatan Aktivitas Pasien Postoperasi Laparatomi
}

\author{
Yuliana $^{1}$, Andrew Johan ${ }^{2}$, Nana Rochana ${ }^{3}$ \\ ${ }^{1}$ Prodi S1 Keperawatan, STIKBA Jambi \\ ${ }^{2,3}$ Fakultas Kedokteran, Universitas Diponegoro Semarang \\ Email: nsyuliana2885@gmail.com
}

Submitted : 20/02/2021

Accepted: 03/03/2021

Published: 06/03/2021

\begin{abstract}
Laparatomy is surgery of the abdomen to open the lining of the abdomen. The treatment reduces complications due to surgery, accelerates healing and restores the patient's function to the maximum extent possible before surgery. Returns physical function immediately after surgery with early mobilization. The purpose of this study was to look at the effect of early mobilization on wound healing and increased patient activity postoperatively in laparotomy. This type of research is quantitative with quasy eksperiment with control gruop designs. The number of samples was 88 Laparatomi patients, taken using purposive sampling technique. Tool of data using observation sheets. Data were analyzed using chi-square test and Wilcoxon test. The results of the study stated that there were significant differences between the control group and the intervention group on wound healing $(p=0.047)$ and on increased activity $(p=0.005)$. The results of the study it can be concluded that there is an influence of early mobilization on wound healing and increased patient activity. The results of this study recommend early mobilization using progressive mobility procedures in accordance with client activity intolerance.
\end{abstract}

Keywords: activity level, laparatomi, wound healing,

\begin{abstract}
Abstrak
Laparatomi yaitu pembedahan abdomen sampai membuka selaput abdomen. Perawatannya mengurangi komplikasi akibat pembedahan, mempercepat penyembuhan dan mengembalikan fungsi pasien semaksimal mungkin seperti sebelum operasi. Pengembalian fungsi fisik dilakukan segera setelah operasi dengan mobilisasi dini. Tujuan penelitian ini adalah untuk melihat pengaruh mobilisasi dini terhadap penyembuhan luka dan peningkatan aktivitas pasien postoperasi Laparatomi. Jenis penelitian ini adalah kuantitatif dengan desain quasi eksperiment menggunakan kelompok kontrol. Jumlah sampel sebanyak 88 pasien laparatomi, diambil menggunakan tehnik purposive sampling. Alat ukur instrumen menggunakan lembar observasi. Data dianalisis menggunakan uji chi-square dan uji wilcoxon. Hasil penelitian menyatakan ada perbedaan bermakna antara kelompok kontrol dengan kelompok intervensi pada penyembuhan luka $(\mathrm{P}=0,047)$ dan pada peningkatan aktivitas $(\mathrm{P}=0.005)$. Hasil penelitian menunjukkan bahwa ada pengaruh mobilisasi dini terhadap penyembuhan luka dan peningkatan aktivitas pasien. Hasil penelitian ini merekomendasikan mobilisasi dini menggunakan prosedur mobility progresif sesuai dengan toleransi aktivitas klien.
\end{abstract}

Kata kunci : laparatomi, penyembuhan luka, tingkat aktivitas

\section{PENDAHULUAN}

Laparatomi merupakan salah satu tindakan operasi bedah besar, dengan melakukan penyayatan pada lapisan dinding perut untuk mendapatkan bagian organ perut yang mengalami masalah, misalnya kanker, pendarahan, obstruksi dan perforasi, (Sjamsuhidajat, 2014). Data dari World Health Organization (WHO) menunjukkan jumlah pasien dengan tindakan operasi mengalami peningkatan dari 140 menjadi 148 juta jiwa didunia dari 2011 ke 2012. 
Indonesia pada tahun 2012, mendapatkan hasil tindakan operasi mencapai 1,2 juta jiwa dan diperkirakan $32 \%$ diantaranya merupakan tindakan bedah laparatomi, (Ningrum, 2016). Data rekam medis pasien Rumah Sakit Umum Raden Mattaher Jambi menunjukkan data sebanyak 249 pembedahan laparatomi pada tahun 2017, dimana angka ini menempati urutan ke-2 dari sepuluh tindakan operasi bedah terbanyak yang dilakukan.

Laparatomi yaitu pembedahan abdomen sampai membuka selaput abdomen, (Grace 2007). Tindakan ini memerlukan perawatan yang berkesinambungan. Tindakan perawatan post laparatomi adalah bentuk pelayanan perawatan yang diberikan kepada pasien yang telah menjalani operasi pembedahan perut. Tujuan perawatan post laparatomi antara lain mengurangi komplikasi akibat pembedahan, mempercepat penyembuhan, mengembalikan fungsi pasien semaksimal mungkin seperti sebelum operasi, mempertahankan konsep diri pasien dan mempersiapkan pasien pulang. Salah satu tindakan perawatan post operasi laparatomi adalah mengatur dan menggerakkan posisi pasien dengan hati-hati. Pengembalian fungsi fisik dilakukan segera setelah operasi dengan latihan nafas, batuk efektif dan latihan mobilisasi dini, (Padila, 2012).

Mobilisasi dini yaitu proses aktivitas yang dilakukan pasien setelah operasi dimulai dari latihan ringan diatas tempat tidur sampai pasien bisa turun dari tempat tidur, berjalan ke kamar mandi dan berjalan ke luar kamar. Pada umumnya pasien dengan tindakan bedah diberikan dorongan untuk turun ketempat tidur secepat mungkin, hal ini ditentukan oleh kestabilannya sistem kardiovaskular, neuromuskular pasien, tingkat aktivitas pasien yang lazim dan jenis pembedahan yang dilakukan. Keuntungan mobilisasi dini adalah bahwa hal tersebut menurunkan masalah komplikasi postoperasi seperti, mengurangi distensi abdomen, mempercepat pemulihan pada luka abdomen, mengurangi nyeri pada luka operasi dan mengembalikan pemulihan aktivitas tertentu sehingga pasien dapat kembali normal dan atau dapat memenuhi kebutuhan gerak harian, (Bruner \& suddart, 2002)

Aktivitas adalah suatu energi atau keadaan bergerak dimana manusia memerlukan untuk dapat memenuhi kebutuhan hidup. Adapun sistem tubuh yang berperan dalam kebutuhan aktivitas antara lain: tulang, otot dan tendon, ligamen, sistem saraf dan sendi, (Potter and Perry, 2006).

Ada banyak alasan mengapa pasien enggan bergerak, kebanyakan pasien memiliki rasa khawatir kalau menggerakkan tubuh pada posisi tertentu setelah operasi, khawatir akan menimbulkan nyeri, kerusakan atau bahaya lebih lanjut, (Julia, Abdul majid, 2011). Immobilisasi yang berlangsung lama dapat menyebabkan dampak negatif terhadap sistem tubuh, (Asmadi, 2008). Mempercepat proses penyembuhan dan pemulihan kondisi pasien pascaoperasi perlu diperhatikan, mobilisasi bertahap hingga dapat beraktifitas seperti biasa, semakin cepat dilakukan maka semakin baik, (Majid Abdul, 2011).

Exercise therapy ambulation diberikan pada pasien yang mengalami hambatan mobilisitas fisik atau intoleransi aktivitas dengan tujuan meningkatkan aktivitas klien, (Handayani, 2017).

Therapy ambulasi merupakan bagian gerakan dari mobilasi dini. Ambulasi dini harus jangan melebihi toleransi pasien. Kondisi pasien harus menjadi faktor penentu dan kemajuan langkah diikui dengan memobilisasi pasien. Dukungan dan dorongan keperawatan dan dengan keselamatan sebagai perhatian utama, harus hati-hati untuk tidak membuat pasien letih, lamanya periode ambulasi pertama beragam tergantung pada kondisi fisik, (Brunner \& suddart, 2002). Mobility progresife adalah 
protokol mobilisasi berdasarkan Timmerman (2007) dan American association of critical care nurses (2009) merupakan mobilisasi dimulai dengan safety screening untuk memastikan kondisi fisik pasien, (Handayani, 2017).

Penelitian Aleef dan Labib (2017) tentang early mobilitation and ICU rehabilitiation of ECMO patient, menyatakan bahwa mobilisasi dini mampu meningkatkan fungsi fisik pada pasien extra corporeal membrane oxigenation di ruang ICU. Hasil penelitian Handayani (2017) yaitu adanya peningkatan gerak sendi pada pasien terpasang ventilator pada hari ke tiga dan ketujuh setelah pelaksanaan mobilisasi progressif level satu. Belum ada penelitian yang membuktikan bahwa mobilisasi dini mempengaruhi tingkat aktivitas pasien.

Pascaoperasi pada laparatomi jika tidak mendapatkan perawatan maksimal dapat memperlambat proses penyembuhan. Salah satunya penyembuhan luka operasi. Pada prinsipnya luka akan sembuh dengan sendirinya, setiap luka operasi memiliki keragaman dalam memberikan respon yang dipengaruhi secara lokal dan umum. Jika faktor umum dan lokal tidak ditangani dengan baik luka akan sulit sembuh (Arisanty, 2016), misalnya infeksi luka, kejadian infeksi biasanya muncul pada 36-46 jam setelah operasi, (padila, 2012). Rumah sakit di Indonesia angka kejadian infeksi luka operasi antara 2\%-18\%, (sandy, 2015). Survei WHO menunjukkan bahwa angka kejadian surgical site infection di dunia berkisar antara 5\%-34\%. Infeksi mengakibatkan dehisend dan eviserasi (Brunner \& suddart, 2002). Angka insiden wound dehiscence didunia sekitar 0,4\%-3,5\%, (Ningrum).

Luka seharusnya menutup (sembuh) dalam waktu 21 hari namun terhambat hingga lebih dalam 60 hari bergantung pada tingkat penghambatnya, Arisanty, 2016). Penelitian Kusumayanti (2014) salah satu faktor yang berpengaruh terhadap lamanya perawatan pada pasien pascaoperasi laparatomi di instalasi rawat inap adalah mobilisasi dini dengan nilai sig 0,033. Arifin (2010) menyebutkan ada pengaruh mobilisasi dini terhadap lama hari rawat pasien post operasi laparatomi, pasien dengan mobilisasi rawat inap menjadi lebih singkat $<7$ hari dibandingkan pasien yang tidak melakukan mobilisasi dini dengam rawat inap $\geq 7$ hari.

Beberapa jurnal penelitian membuktikan hasil mobilisasi dini dalam mempercepat penyembuhan luka post operasi. Hasil penelitian Gusti (2011) mengalami peningkatan rata-rata penyembuhan luka post operasi abdomen (bedah mayor dan bedah minor) pada kelompok perlakuan dibandingkan kelompok kontrol dengan uji man whitney nilai $\mathrm{p}=$ 0,000 . Berdasarkan hasil pengamatan peneliti pada kelompok bedah mayor dan minor yang diberikan penyuluhan dan pemantauan mobilisasi, waktu perkembangan penyembuhan luka pada kelompok bedah sama dimana pengangkatan jahitan selang seling sudah bisa dibuka pada hari ke-7 dan hari ke-14 jahitan sudah dapat dilepas semua. Hasil penelitian Ditya (2016) pada 31 pasien pasca laparatomi dibangsal bedah terdapat $54,8 \%$ penyembuhan luka baik, dengan uji chi-square terdapat hubungan yang bermakna antara mobilisasi dini dengan proses penyembuhan luka $(\mathrm{p}=0,003)$.

Hasil observasi dan wawancara yang dilakukan di Ruang ICU Rumah Sakit Umum Raden Mattaher Jambi, perawat menyatakan pasien postoperasi dipantau selama enam jam, jika kondisi pasien membaik dipindahkan keruang rawat inap, dan mobilisasi berkemungkinan dilakukan di ruang rawat inap, survei yang didapat di ruang rawat inap mobilisasi dilakukan di hari ke-3 dan kemampuan aktivitas pasien untuk duduk maupun berjalan sangat lamban. Keterlambatan mobilisasi sangat 
mempengaruhi aktivitas klien dan penyembuhan luka. Bagi pasien merasa sembuh adalah jika membaiknya luka operasi dan kemampuan beraktivitas seperti sebelum pembedahan. Hal inilah yang membuat peneliti tertarik untuk mengambil mobilisasi dini, penyembuhan luka dan peningkatan aktivitas sebagai variabel yang akan diteliti.

Penelitian Aleef Muriyan CM. dan Labib ahmed (2017) mendapatkan hasil bahwa mobilisasi dini meningkatkan pemulihan fisik, penelitian Halida Handayani (2017) mendapatkan hasil mobilisasi progressife level satu efektif dalam perubahan rentang gerak sendi. Pembuktian mobilisasi dini terhadap peningkatan aktivitas pasien belum ada. Beberapa jurnal penelitian mendapatkan hasil mobilisasi dini mempercepat proses penyembuhan luka, belum ada jurnal internasional terkait hal ini.

Dari beberapa jurnal penelitian tersebut menggunakan tahapan prosedur mobilisasi yang berbeda, antara lain Kasdu (2003) dalam penelitian Netty (2013) memulai prosedur 6 jam pascaoperasi, penelitian Sumartinah (2014) memulai prosedur 2-6 jam pasca operasi. Penelitian Handayani (2017) menggunakan protokol mobility progresife memulai prosedur delapan jam pasca operasi. Penelitian Conceicao (2017), menjelaskan dari berbagai sistematik review didapatkan pasien aman melakukan mobilisasi jika memenuhi kriteria ketetapan kardiovaskular, respirasi, neurologi, orthopedic, dan ketetapan lainnya.

Ditinjau dari beberapa rumah sakit umum yang ada di Indonesia antara lain RSUD Abdul Manap Jambi, RSUD Raden Mattaher Jambi, RSUP M. Djamil Padang, Rumah Sakit Fatmawati Jakarta, belum memiliki protokol atau SOP mobilisasi dini diruangan. Rumah Sakit Ahmad di Doha Qatar mempunyai protocol mobilisasi dini yang dapat digunakan di ruang ICU dan ruang Bedah. Pasien dilakukan safety screening sebelum mobilisasi, dari penilaian tersebut menentukan level toleransi aktivitas pasien. Protokol ini digunakan sebagai alat instrumen untuk intervensi mobilisasi dini dan melihat efek terhadap penyembuhan luka dan tingkat aktivitas pasien. Peneliti berharap penelitian ini menjadi gambaran bagi pasien manfaat mobilisasi dini terhadap penyembuhan luka dan peningkatan aktivitas pasien postoperasi laparatomi.

\section{METODE PENELITIAN}

Penelitian ini merupakan penelitian quasi-eksperiment, (Supardi, 2013). Penelitian ini menggunakan dua rancangan penelitian yaitu, rancangan penelitian posttest-only control gruop design dan rancangan penelitian pretest-posttest control gruop design. Rancangan penelitian posttestonly control gruop design yaitu desain penelitian yang memiliki dua kelompok, yaitu kelompok kontrol dan kelompok intervensi dilakukan dengan cara nonrandomisasi kemudian dilakukan evaluasi sesudah diberikan perlakuan. Rancangan penelitian pretest-posttest control gruop design yaitu suatu desain penelitian yang memiliki dua kelompok yaitu kelompok kontrol dan kelompok intervensi dilakukan dengan cara non-randomisasi yang kemudian dievaluasi sebelum dan sesudah diberikan perlakuan, (Dwiyantini, 2018).

Populasi pada penelitian ini adalah seluruh pasien postoperasi laparatomi di Rumah Sakit Umum Raden Mattaher Jambi dan Rumah Sakit Umum Daerah Abdul Manap. Tehnik sampling adalah cara penyeleksian porsi populasi untuk dapat mewakili populasi. Menggunakan tehnik sampling merupakan cara yang ditempuh dalam pengambilan sampel, agar memperoleh sampel yang benar-benar sesuai dengan subjek yang diinginkan peneliti Metode purposive sampling yaitu pemilihan 
sampel dengan menetapkan subjek yang memenuhi kriteria dimasukkan dalam kurun waktu tertentu sehingga jumlah responden yang diperlukan terpenuhi (Nursalam, 2014). Kriteria inklusi:

a. Pasien pascaoperasi laparatomi $\leq 72$ jam.

Kriteria eksklusi:

a. Gangguan metabolik (Diabetess mellitus)

b. Gangguan multisistem (jantung, muskular, neurologis, pernafasan)

c. Order dokter adanya pembatasan dalam mobilisasi dini

Dengan jumlah sample 88 pasien post operasi laparatomi (44 kelompok intervensi dan 44 kelompok kontrol). Dengan analisis data menggunakan uji chi-square dan uji wilxocon, (Dwiyantini, 2018). Penelitian ini dilakukan di Rumah Sakit Umum Raden Mattaher Jambi dan Rumah Sakit Umum Daerah Abdul Manap kota Jambi. Waktu pelaksanaan penelitian dibulan Desember 2018-Mei 2019.
Instrumen penelitian menggunakan tiga alat ukur yaitu, protokol mobilisasi dini sebagai SOP mobilisasi dini, lembar obsevasi pengkajian luka yang digunakan untuk mengukur penyembuhan luka dan lembar observasi tingkat aktivitas untuk mengukur peningkatan aktivitas pasien postoperasi laparatomi. Penelitian ini telah lolos uji etik yang dilaksanakan oleh Komite Etik Penelitian kesehatan fakultas universitas Aisiyah Yogyakarta. Prosedur penelitian adalah, mengukur tingkat aktivitas responden sebelum diberikan intervensi, setelah itu melakukan mobilisasi dini berdasarkan acuan protokol mobilisasi dini selama 5 hari. Follow up dilakukan di hari ke 5 untuk mengukur tingkat aktivitas dan penyembuhan luka operasi setelah diberikan tindakan mobilisasi dini. Data dikumpulkan oleh peneliti sendiri sedangkan tindakan mobilisasi dibantu oleh perawat ruangan yang telah diberikan penjelasan terlebih dahulu.

\section{HASIL DAN PEMBAHASAN}

Karakteristik pasien post laparatomi

Tabel.1 karakteritik pasien post operasi laparatomi.

\begin{tabular}{|c|c|c|c|c|c|c|c|}
\hline \multirow{2}{*}{ No } & \multirow{2}{*}{ Variabel } & \multicolumn{2}{|c|}{ Intervensi } & \multicolumn{2}{|c|}{ Kontrol } & \multirow{2}{*}{$x^{2}$} & \multirow{2}{*}{$\begin{array}{c}\text { Homogenitas } \\
\mathrm{p}\end{array}$} \\
\hline & & $F$ & $\%$ & $F$ & $\%$ & & \\
\hline 1. & \begin{tabular}{ll}
\multicolumn{2}{l}{ Jenis kelamin } \\
a. & Laki-laki \\
b. & perempuan \\
& Total \\
\end{tabular} & $\begin{array}{r}35 \\
9 \\
44 \\
\end{array}$ & $\begin{array}{c}79,5 \% \\
20,5 \% \\
100 \% \\
\end{array}$ & $\begin{array}{r}35 \\
9 \\
44 \\
\end{array}$ & $\begin{array}{c}79,5 \% \\
20,5 \% \\
100 \% \\
\end{array}$ & $0,002^{\mathrm{a}}$ & 1.000 \\
\hline 2. & $\begin{array}{l}\text { Usia } \\
\text { a. Dewasa } \\
\text { b. Lansia } \\
\text { Total } \\
\end{array}$ & $\begin{array}{c}22 \\
22 \\
44 \\
\end{array}$ & $\begin{array}{c}50 \% \\
50 \% \\
100 \% \\
\end{array}$ & $\begin{array}{c}23 \\
21 \\
44 \\
\end{array}$ & $\begin{array}{c}52,3 \% \\
47,7 \% \\
100 \% \\
\end{array}$ & $0,091^{\mathrm{a}}$ & 0,763 \\
\hline 3. & $\begin{array}{l}\text { Status } \\
\text { a. Menikah } \\
\text { b. Belum menikah } \\
\text { Total } \\
\end{array}$ & $\begin{array}{l}32 \\
12 \\
44\end{array}$ & $\begin{array}{c}72,7 \% \\
27,3 \% \\
100 \%\end{array}$ & $\begin{array}{c}35 \\
9 \\
44\end{array}$ & $\begin{array}{c}79,5 \% \\
20,5 \% \\
100 \%\end{array}$ & $0.146^{\mathrm{a}}$ & 1.000 \\
\hline 4. & $\begin{array}{l}\text { Pendidikan } \\
\text { a. SD \& SMP } \\
\text { b. SMA, D3 \& S1 } \\
\text { Total }\end{array}$ & $\begin{array}{l}14 \\
30 \\
44 \\
\end{array}$ & $\begin{array}{r}31,8 \% \\
68,2 \% \\
100 \% \\
\end{array}$ & $\begin{array}{c}12 \\
32 \\
44 \\
\end{array}$ & $\begin{array}{c}27,3 \% \\
72,7 \% \\
100 \% \\
\end{array}$ & $2.514^{\mathrm{a}}$ & 0,152 \\
\hline
\end{tabular}


5. Diagnosa

a. Kolesistektomi/kolelitiasis

c. Peritonitis, perforasi, APP perforasi

d. Ca. Recti 1/3 distal

e. Appendiktomy, APP akut

f. Ca. Pangkreas

g. Trauma tumpul

h. Herniaraphy/hernia

i. Kolik ileus, kolik abdomen

j. Ruptur hepar

k. Kolostomy

1. Sigmoidektomy

m. Ca. Colon

n. Radical systectomy

o. Repair gaster Total b. Ca. Empedu

7
1
12

1
5
1
1
6
4
0
2
3
1
0
0
44

$15,9 \%$
$2,3 \%$
$27,3 \%$

$2,3 \%$
$11,4 \%$
$2,3 \%$
$2,3 \%$
$13,6 \%$
$9,1 \%$
$0 \%$
$4,5 \%$
$6,8 \%$
$2,3 \%$
$0 \%$
$0 \%$
$100 \%$

$11,4 \%$
$0 \%$
$20,5 \%$

$2,3 \%$
$20,5 \%$
$0 \%$
$0 \%$
$15,9 \%$
$6,8 \%$
$4,5 \%$
$4,5 \%$
$11,4 \%$
$0 \%$
$2,3 \%$
$2,3 \%$
$100 \%$

$0 \%$

$\%$
Setelah transformasi data menjadi tabel $2 \times 2$

Tabel.1 distribusi karakteristik responden hampir merata antara kelompok kontrol dan kelompok intervensi, jenis kelamin laki-laki 35 responden $(79,5 \%)$ pada tiap kelompok, usia dewasa dengan rentang usia 14-45 tahun pada kelompok kontrol 23 responden $(52,3 \%)$ dan pada kelompok intervensi 22 responden $(50 \%)$, status menikah pada kelompok kontrol 35 responden $(79,5 \%)$ dan pada kelompok intervensi 32 responden $(72,7 \%)$, pendidikan tingkat SMA, D3 dan S1 pada kelompok kontrol 32 responden $(72,7 \%)$ dan pada kelompok intervensi 30 responden $(68,2 \%)$, diagnosa peritonitis, perforasi dan APP perforasi pada kelompok intervensi $(27,3 \%)$ dan pada kelompok kontrol (20,5\%). Uji homogenitas karakteristik responden baik jenis kelamin, usia, status, pendidikan, diagnosa medis, mempunyai nilai signifikansi $>0,05$ sehingga dapat dikatakan bahwa varian dari kelompok intervensi maupun kelompok kontrol adalah sama atau homogen

Penyembuhan luka operasi pasien post laparatomi Tabel.2 Pengaruh mobilisasi dini terhadap penyembuhan luka

\begin{tabular}{|c|c|c|c|c|c|c|c|c|c|}
\hline \multirow[b]{2}{*}{ Penyembuhan Luka } & \multicolumn{2}{|c|}{ Intervensi } & \multicolumn{2}{|c|}{ Kontrol } & \multicolumn{2}{|c|}{ Total } & \multirow{2}{*}{$\begin{array}{c}\mathbf{O R} \\
(95 \% \mathrm{CI})\end{array}$} & \multirow[b]{2}{*}{$x^{2}$} & \multirow[b]{2}{*}{$\mathbf{p}$} \\
\hline & $f$ & $\%$ & $F$ & $\%$ & $F$ & $\%$ & & & \\
\hline Sempurna & 40 & $45,5 \%$ & 33 & $37,5 \%$ & 73 & $83 \%$ & & & \\
\hline Tidak sempurna & 4 & $4,5 \%$ & 11 & $12,5 \%$ & 15 & $17 \%$ & 3.333 & $3,938^{\mathrm{a}}$ & 0,047 \\
\hline Total & 44 & $50 \%$ & 44 & $50 \%$ & 88 & $100 \%$ & & & \\
\hline
\end{tabular}

Tabel. 2 Hasil penelitian menunjukkan penyembuhan luka sempurna pada kelompok intervensi sebanyak 40 responden $(45,5 \%)$ lebih dari kelompok kontrol 33 responden $(37,5 \%)$, sedangkan penyembuhan luka tidak sempurna pada kelompok intervensi 4 responden $(4,5 \%)$ lebih kecil dibanding kelompok kontrol 11 responden (12,5\%). Hasil uji analisis menunjukkan adanya perbedaan bermakna antara kelompok kontrol 
dengan kelompok intervensi $(\mathrm{p}=0,047)$. Dari hasil analisis diperoleh nilai $\mathrm{OR}=3.333$

Aktivitas pasien postoperasi laparatomi

Tabel 3 level toleransi hari ke-5 berdasarkan progressife mobility kelompok

\begin{tabular}{|c|c|c|c|c|c|c|c|c|}
\hline \multirow{4}{*}{ Aktivitas } & \multicolumn{6}{|c|}{ Intervensi } & \multirow{2}{*}{\multicolumn{2}{|c|}{ Total }} \\
\hline & \multicolumn{6}{|c|}{ Level mobility progresif } & & \\
\hline & \multicolumn{2}{|c|}{3} & \multicolumn{2}{|c|}{4} & \multicolumn{2}{|c|}{5} & & \\
\hline & $f$ & $\%$ & $F$ & $\%$ & $F$ & $\%$ & $f$ & $\%$ \\
\hline 1. Mandiri & & & & & 7 & $15,9 \%$ & 7 & $15,9 \%$ \\
\hline 2. Menggunakan alat & & & & & 13 & $29,5 \%$ & 13 & $29,3 \%$ \\
\hline 3. Bantuan atau pengawasan & & & 13 & $29,5 \%$ & 3 & $6,8 \%$ & 16 & $36,4 \%$ \\
\hline $\begin{array}{l}\text { 4. Bantuan, pengawasan dan } \\
\text { peralatan }\end{array}$ & 4 & $9,1 \%$ & 4 & $9,1 \%$ & & & 8 & $18,2 \%$ \\
\hline Total & 4 & $9,1 \%$ & 17 & $38,6 \%$ & 23 & $52,3 \%$ & 44 & $100 \%$ \\
\hline
\end{tabular}

Tabel 3 Menunjukkan bahwa sebagian besar mandiri, 13 responden aktivitas pasien berada pada level 5 dengan kategori 7 menggunakan alat dan 3 responden dengan responden mampu beraktivitas secara aktivitas bantuan atau pengawasan

Tabel 4 level toleransi hari ke-5 berdasarkan progressif mobility kelompok

\begin{tabular}{|c|c|c|c|c|c|c|c|c|c|c|}
\hline \multirow{4}{*}{ Aktivitas } & \multicolumn{8}{|c|}{ Kontrol } & \multirow{2}{*}{\multicolumn{2}{|c|}{ Total }} \\
\hline & \multicolumn{8}{|c|}{ Level mobility progresif } & & \\
\hline & \multicolumn{2}{|r|}{2} & \multicolumn{2}{|r|}{3} & \multicolumn{2}{|r|}{4} & \multicolumn{2}{|r|}{5} & & \\
\hline & $f$ & $\%$ & $f$ & $\%$ & $F$ & $\%$ & $F$ & $\%$ & $f$ & $\%$ \\
\hline 1. Mandiri & & & & & & & 2 & $4,5 \%$ & 2 & $4,5 \%$ \\
\hline 2. Menggunakan alat & & & & & & & 5 & $11,4 \%$ & 5 & $11,4 \%$ \\
\hline 3. Bantuan atau pengawas & & & & & 7 & $15,9 \%$ & 10 & $22,7 \%$ & 17 & $38,6 \%$ \\
\hline $\begin{array}{l}\text { 4. Bantuan, pengawasan dan } \\
\text { peralatan }\end{array}$ & 9 & $20,5 \%$ & 6 & $13,6 \%$ & 5 & $11,4 \%$ & & & 20 & $45,5 \%$ \\
\hline Total & 9 & $20,5 \%$ & 6 & $13,6 \%$ & 12 & $27,3 \%$ & 17 & $38,6 \%$ & 44 & $100 \%$ \\
\hline
\end{tabular}

Tabel 4 menunjukkan bahwa sebagian besar pasien berada pada level 5 dengan kategori 2 responden mampu beraktivitas Tabel 5 aktivitas responden secara mandiri, 5 responden aktivitas menggunakan alat dan 10 responden dengan aktivitas bantuan atau pengawasan

\begin{tabular}{|c|c|c|c|c|c|c|c|c|}
\hline \multirow{3}{*}{ Aktivitas } & \multicolumn{4}{|c|}{ Intervensi } & \multicolumn{4}{|c|}{ Kontrol } \\
\hline & \multicolumn{2}{|c|}{ Pre test } & \multicolumn{2}{|c|}{ Post test } & \multicolumn{2}{|c|}{ Pre test } & \multicolumn{2}{|c|}{ Post test } \\
\hline & $f$ & $\%$ & $f$ & $\%$ & $f$ & $\%$ & $F$ & $\%$ \\
\hline 1. Mandiri & 0 & 0 & 7 & $15,9 \%$ & 0 & 0 & 2 & $4,5 \%$ \\
\hline 2. Menggunakan alat & 0 & 0 & 13 & $29,5 \%$ & 0 & 0 & 5 & $11,4 \%$ \\
\hline 3. Bantuan atau pengawasan & 0 & 0 & 16 & $36,5 \%$ & 0 & 0 & 17 & $38,6 \%$ \\
\hline \multirow{2}{*}{$\begin{array}{l}\text { 4. Bantuan,pe } \\
\text { 5. Ketergantu }\end{array}$} & 0 & 0 & 8 & $18,2 \%$ & 0 & 0 & 20 & $45,5 \%$ \\
\hline & 44 & $100 \%$ & 0 & 0 & 44 & $100 \%$ & 0 & 0 \\
\hline Total & 44 & $100 \%$ & 44 & $100 \%$ & 44 & $100 \%$ & 44 & $100 \%$ \\
\hline
\end{tabular}


Tabel 5 Hasil penelitian menunjukkan bahwa aktivitas responden pada kelompok intervensidan kelompok kontrol sebelum dilakukan mobilisasi mengalami ketergantung penuh (100\%). Setelah dilakukan mobilisasi dini pada kelompok intervensi,aktivitas denganbantuan atau pengawasan sebanyak 16 responden (36,5\%), sedangkan pada kelompok kontrol bantuan, pengawasan dan peralatan 20 responden $(45,5 \%)$.

Tabel 6 Nilai rata-rata aktivitas pre dan post mobilisasi

\begin{tabular}{cccccc}
\hline \multirow{2}{*}{ Kelompok } & \multicolumn{2}{c}{ Pre } & Mean & Post \\
\cline { 2 - 5 } & Mean & SD & 2,57 & 0.974 \\
\hline Intervensi & 5 & 0.000 & 3,25 & 0.839 \\
\hline Kontrol & 5 & 0.000 & &
\end{tabular}

Tabel 6 Hasil penelitian menunjukkan bahwa rata-rata kelompok intervensi dan kelompok kontrol sebelum diberi perlakuan dengan kategori membutuhkan bantuan penuh perawatan, setelah diberi perlakuan rata-rata pada kelompok intervensi membutuhkan bantuan peralatan dan pada kelompok kontrol rata-rata membutuhkan bantuan atau pengawasan orang lain.

Tabel 7 Mobilisasi dini terhadap peningkatan aktivitas

\begin{tabular}{ccc}
\hline Kelompok & $\mathbf{Z}$ & $\mathbf{P}$ \\
\hline Intervensi & $-5,836$ & 0,000 \\
\hline Kontrol & -5.886 & 0,000 \\
\hline
\end{tabular}

Tabel 7 Hasil analisis menunjukkan ada perlakuan pada kelompok intervensi dan juga perbedaan bermakna sebelum dan sesudah kelompok kontrol $(\mathrm{p}=0,000)$

Tabel 8 Pengaruh mobilisasi dini terhadap peningkatan aktivitas

\begin{tabular}{|c|c|c|c|c|c|c|c|c|c|}
\hline \multirow{3}{*}{ Aktivitas } & \multirow{2}{*}{\multicolumn{2}{|c|}{$\begin{array}{c}\text { Intervensi } \\
\text { Post test }\end{array}$}} & \multirow{2}{*}{\multicolumn{2}{|c|}{\begin{tabular}{|l} 
Kontrol \\
Post test
\end{tabular}}} & \multirow{2}{*}{\multicolumn{2}{|c|}{ Total }} & \multirow{3}{*}{$\begin{array}{c}\text { OR } \\
(95 \% \mathrm{CI})\end{array}$} & \multirow{3}{*}{$x^{2}$} & \multirow{3}{*}{$\mathbf{P}$} \\
\hline & & & & & & & & & \\
\hline & $f$ & $\%$ & $f$ & $\%$ & $f$ & $\%$ & & & \\
\hline \multirow{2}{*}{$\begin{array}{l}\text { 1. Mandiri atau menggunakan alat } \\
\text { 2. Bantuan atau pengawasan, dan } \\
\text { atau bantuan, pengawasan dan } \\
\text { peralatan }\end{array}$} & 19 & $21,6 \%$ & 7 & $8 \%$ & 26 & $29,5 \%$ & & & \\
\hline & 25 & $28,4 \%$ & 37 & $42 \%$ & 62 & $70,5 \%$ & 4,017 & $7.861^{\mathrm{a}}$ & 0.005 \\
\hline Jumlah & 44 & $50 \%$ & 44 & $50 \%$ & 88 & $100 \%$ & & & \\
\hline
\end{tabular}

Pada tabel 8 Hasil analisis menunjukkan bahwa setelah diberi perlakuan, adanya perbedaan bermakna antara kelompok kontrol dan kelompok intervensi $(\mathrm{p}=0.005)$. Dari hasil analisis diperoleh nilai $\mathrm{OR}=4,017$ 


\section{Pengaruh penyembuhan luka post operasi laparatomi}

Hasil penelitian dari 88 responden yang terbagi menjadi 44 kelompok intervensi dan 44 kelompok kontrol menunjukkan bahwa setelah diberikan mobilisasi dini penyembuhan luka responden sempurna pada kelompok intervensi 40 responden $(45,5 \%)$ lebih dari kelompok kontrol sebanyak 33 responden $(37,5 \%)$ Kondisi luka klien tampak sempurna dengan kondisi luka tidak ada jaringan nekrotik, granulasi sempurna, epitelisasi menyatu sempurna, cairan eksudat sedikit dengan warna jernih, tidak terlihat tanda-tanda infeksi, tepi luka tampak halus, bersih, tipis dan lunak, dan kulit sekitar luka tampak utuh, status penyembuhan luka meningkat. Hasil penelitian menunjukkan terdapat 4 responden $(4,5 \%)$ penyembuhan luka tidak sempurna pada kelompok intervensi, jumlah yang lebih sedikit dibanding kelompok kontrol sebanyak 11 responden $(12,5 \%)$ Kondisi luka tampak ada jaringan nekrotik, pada sebagian jahitan luka epitelisasi belum menutup sempurna, terdapat sedikit cairan eksudat berbentuk puss/nanah bewarna kuning, terdapat tanda infeksi salah satunya jaringan granula rapuh, kerusakan luka seperti jahitan luka terbuka, kulit sekitar luka kemerahan dan bewarna kebiruan, status luka memburuk.

Hasil uji statistik penelitian menunjukkan adanya perbedaan bermakna antara kelompok kontrol dengan kelompok intervensi ( $\mathrm{p}=0,047)$. Hal ini sejalan dengan hasil penelitian Gusty (2011) hasil uji statistik adanya perbedaan bermakna antara kelompok kontrol dengan kelompok intervensi ( $\mathrm{p}=$ 0,003). Mobilisasi mempercepat pemulihan pada luka abdomen (Haswita, 2017) bertujuan menurunkan komplikasi pasca operasi seperti masalah sirkulasi. Aliran darah lancar sangat penting pada pasien setelah pembedahan dan pada proses penyembuhan luka secara umum. Pembuluh darah arteri menghantar darah yang berisi nutrisi dan oksigen yang sangat bermanfaat bagi perkembangan sel dalam tubuh. Jika aliran darah ini terhambat datang ke area luka setelah operasi karena alasan tertentu, luka akan mengalami sianosis hingga akhirnya mengalami nekrosis dan luka tidak sembuh sesuai waktu penyembuhan, (Theddeus, 2016). Gangguan pergerakan dapat menghambat aliran darah dari dan ke perifer, sering kali pemilik luka tidak merasakan kondisi lukanya memburuk dalam hal ini asuhan keperawatan diperlukan untuk meningkatkan penyembuhan luka dan pencegahan infeksi, (Arisanty, 2016).

\section{Pengaruh mobilisasi dini terhadap} aktivitas pasien postoperasi laparatomi

Hasil penelitian menunjukkan bahwa pasca operasi sebelum diberikan mobilisasi dini seluruh responden memerlukan bantuan penuh perawat (100\%), hal ini dikarenakan pada pasien pascaoperasi mengalami hambatan mobilisasi pengaruh dari anastesi dan rasa nyeri pasca operasi ${ }^{5}$. Peningkatan aktivitas kelompok intervensi dengan kelompok kontrol tampak setelah follow-up hari ke-5. Pada kelompok intervensi, aktivitas dengan bantuan atau pengawasan sebanyak 16 responden $(36,5 \%)$ lebih satu tingkat dibandingkan kelompok kontrol yang memerlukan bantuan, pengawasan dan peralatan sebanyak 20 responden $(45,5 \%)$. Hasil uji statistik menunjukkan adanya perbedaan bermakna antara kelompok kontrol dengan kelompok intervensi $(\mathrm{p}=0,005)$. Untuk penelitian terkait mobilisasi dini terhadap peningkatan aktivitas pasien pascaoperasi laparatomi belum ada.

Aktivitas adalah suatu energi atau keadaan bergerak dimana manusia memerlukan untuk dapat memenuhi kebutuhan hidup, (Hidayat, 2006). kebanyakan orang menilai tingkat kesehatannya berdasarkan kemampuannya 
untuk melakukan aktivitas seperti berdiri, berjalan, bekerja, makan, minum dan lain sebagainya, (Mubaraq, 2015). Adapun sistem tubuh yang berperan dalam kebutuhan aktivitas antara lain sistem persyarafan dan muskuloskeletal. Sistem muskuloskeletal terdiri dari: tulang, otot dan tendon, ligamen, sistem saraf dan sendi. Apa bila dilakukan dengan baik dan benar, aktifitas atau gerak tubuh sangat bermanfaat bagi seseorang. Gerak tubuh secara teratur memperbaiki tonus otot, merangsang peredaran darah dan organ tubuh yang lain sehingga dapat meningkatkan kalenturan tubuh (Asmadi, 2008).

Pergerakan yang dilakukan pada pasien memberi energi untuk mengembalikan kemampuan aktivitas pasien, semakin cepat pasien bergerak pasca operasi, semakin baik pemulihan fisik klien, yang berdampak pada aktivitas klien, (Brunner and Suddart, 2002). Immobilisasi yang lama dapat menyebabkan dampak yang negatif pada sistem organ tubuh. Penurunan kekutan otot juga mempengaruhi otot pernafasan, selanjutnya hal ini menurunkan kapasitas vital dan kapasitas fungsional pernafasan. Bedrest yang terus menerus akan menurunkan energi yang dibutuhkan sehingga menurunkan kecepatan Basal Metabolik Rate, (Asmadi, 2008). Kebanyakan dari pasien masih mempunyai kekhawatiran kalau tubuh digerakkan pada posisi tertentu pascaoperasi akan mempengaruhi luka operasi yang masih belum sembuh yang baru saja selesai dikerjakan. Padahal tidak sepenuhnya masalah ini perlu dikhawatirkan, bahkan justru hampir semua jenis operasi membutuhkan mobilisasi atau pergerakan badan sedini mungkin, asalkan rasa nyeri dapat ditahan dan keseimbangan tubuh tidak lagi menjadi gangguan, dengan bergerak, masa pemulihan untuk mencapai level kondisi seperti pra pembedahan dapat dipersingkat, dapat disimpulkan pergerakan yang dilakukan pada pasien memberi energi untuk mengembalikan kemampuan aktivitas pasien, semakin cepat pasien bergerak pasca operasi, semakin baik pemulihan fisik klien, yang berdampak pada aktivitas klien, (Brunner and Suddart, 2002).

\section{SIMPULAN}

Ada pengaruh mobilisasi dini terhadap penyembuhan luka pasien postoperasi laparatomi. Ada pengaruh mobilisasi dini terhadap peningkatan aktivitas pasien postoperasi laparatomi

\section{SARAN}

$\begin{array}{ccr}\text { Hasil } & \text { penelitian } & \text { ini } \\ \text { merekomendasikan } & \text { mobilisasi } & \text { dini }\end{array}$ menggunakan prosedur mobility progresif sesuai dengan toleransi aktivitas klien.

\section{UCAPAN TERIMA KASIH}

Terima kasih kepada Muhammad Aleef fisiotherapi rumah sakit umum Ahmad Qatar yang telah membantu dalam penjelasan protokol mobilisasi RSU. Ahmad Qatar.

\section{DAFTAR PUSTAKA}

Aleef MCM, Labib A. Early mobilitation and ICU rehabilitation of ECMO patients. Qatar medical jurnal. 2017; Art 71

Amin Huda. Aplikasi asuhan keperawatan berdasarkan diagnose medis dan NANDA NIC-NOC. Jakarta: Mediaction; 2015

Asmadi. Teknik prosedur keperawatan konsep dan dasar aplikasi kebutuhan dasar klien. Jakarta: Salemba medica; 2008

Arisanty IP. Konsep dasar manajemen perawatan. Jakarta: EGC; 2106

Arifin Dahlia. Pengaruh mobilisasi dini terhadap lama hari rawat pasien postoperasi di RSU Haji Makasar. Skripsi. 2010 
Brunner and Suddarth. Buku ajar keperawatan medical bedah. Jakarta: EGC; 2002

Conceicao TMA, Gonzales AI, Figueiredo FCXS, Vieira DSR, Bundchen DC. Safety criteria to strat early mobilization in intensive care units. Systematic review. Rev bras ter intensiva. 2017; 29 (4); 509-519 Ditya W, Zahari A, Afriwadi. Hubungan mobilisasi dini dengan proses penyembuhan luka pada pasien pasca laparatomi di bangsal bedah pria dan wanita RSUP Dr. M. Djamil Padang. Jurnal kesehatan Andalas. 2016; 5(3); 724-729

Dwiyantini M, Puspitaningrum I, Herlina, Wiguna RI, Ningsih HEW. Penelitian quasi-eksperiment dalam keperawatan. Semarang: UNDIP PRESS; 2018Grace PA. At a glacei ilmu bedah, edisi 3 . Jakarta: Erlangga; 2007

Gusty RP. Pengaruh mobilisasi dini pasien pascaoperasi abdomen terhadap penyembuhan luka dan fungsi pernafasan. Ners jurnal keperawatan. 2011; 7(2); 106-113

Handayani Halidai. Efek mobilisasi progressife terhadap perubahan derajat rentang gerak sendi dan kadar asam laktat pada pasien dengan ventilasi mekanik di unit perawatan intensif (ICU). Tesis; 2017

Haswita, Sulistyowati R. Kebutuhan dasar manusia untuk mahasiswa Simangungso R, Rottie J, Hutauruk M. Hubungan mobilisasi dini dengan proses penyembuhan luka post section caesarea di RSU GMIM Pancaran kasih Manado. E-journal keperawatan. 2018; 6(1);1-6

Hidayat AA. Kebutuhan dasar manusia. Jakarta: Salemba Medica; 2006 Julia DK, Peter SD. Keperawatan ortopedik dan trauma. Jakarta: EGC; 2011
Kusumayanti, Devi NLP, Dian NM, Astriani LPN. Faktor-faktor yang mempengaruhi terhadap lamanya perawatan pada pasien pascaoperasi laparatomi di instalasi rawat inap BRSU Tabanan. JAP. 2014; 2(3); 186-193

Keperawatan dan kebidanan. Jakarta: Trans Info Media; 2017 Majid Abdul. Keperawatan perioperatif. Yogyakarta: Goysen publishing; 2011

Mubarak WI, Indrawati L, Susanto J. Buku ajar ilmu keperawatan dasar. Jakarta: Salemba medica; 2015

Netty Indarmein. Hubungan mobilisasi dini dengan penyembuhan luka postoperasi seksiosesarea di ruang rawat gabung kebidanan RSUD H. Abdul Manap kota Jambi tahun 2012. Jurnal penelitian universitas Jambi serie sains. 2013; 15(1); 59-70 Ningrum TP, Isabela $C$. Gambaran karakteristik pasien wound dehiscence menurut variabel Rotterdam di RSUD kota Bandung. Jurnal ilmu keperawatan. 2016; IV (2): 111-115.

Nursalam. Metodologi penelitian ilmu keperawatan, edisi 3. Jakarta: Salemba Medica; 2014 Padila. Buku ajar keperawatan medical bedah. Yogyakarta: Nuha medica; 2012

Potter and Perry. Buku ajar fundamental keperawatan, edisi 4. Jakarta: EGC; 2006

Rahma N, Kasim J, Anggriani S. Hubungan mobilisasi dini terhadap kesembuhan luka pada pasien section caesarea di RSKD ibu dan anak Siti Fatimah Makasar. Jurnal ilmiah kesehatan. 2015; 5(6); 655-660

Sandy FPT, Yulinar R, Utami NW. Infeksi luka operasi pada pasien postoperasi laparatomi. Jurnal keperawatan terapan.2015; (1); 14-24

Sjamsuhidajat, Wimde J. Buku ajar ilmu bedah, edisi 3, volume 1. Jakarta: EGC; 2014 
Sumartinah, Kusyati E, kustriyanti D, Rahayu H. Hubungan mobilisasi dini dan kadar hemoglobin terhadap penyembuhan luka operasi section caesarea di Semarang. Prosiding konferensi nasional II PPNI Jawa Tengah.2014; 2(1); 237-241

Sumarah, Marianingsih E, Kusnanto $H$, Haryanti W. Pengaruh mobilisasi dini terhadap penyembuhan luka post section caesarea. Jurnal involsi kebidanan. 2013; 3(5); 58-69
Supardi S, Rustika. Metodelogi riset keperawatan. Jakarta; Trans Info Media; 2013

Susantika IY. Mobilisasi dini terhadap penyembuhan luka paska seksio sesaria di RSU.Wahidin Sudiro Husodokota Mojokerto. Jurnal.2015;2(1); 1-7 Theddeus $\mathrm{OH}$, Prasetyono. Panduan klinis manajemen luka. Jakarta: EGC;2016

Yuwono. Pengaruh beberapa faktor resiko terhadap kejadian surgical site infection (SSI) pada pasien laparatomi emergensi. JMJ; 1(1); 16-25 